\title{
Esterino Adami
}

More than Language and Literature: Postcolonial Connections and Linguistic Paradigms in Hansda Sowvendra Shekhar's Indian English Fiction

\begin{abstract}
I: L'articolo tratta dei legami transdisciplinari fra lingua e letteratura nel contesto postcoloniale, concentrandosi sulla scena letteraria indiana di lingua inglese. L'articolo sottolinea l'importanza di un approccio al testo letterario che tenga presente aspetti linguistici per svelare complesse questioni identitarie. In quest'ottica, viene presentata un'analisi preliminare di alcuni racconti tratti da The Adivasi Will Not Dance (2017) di Hansda Sowvendra Shekhar, uno scrittore della comunità adivasi, i cosiddetti 'tribali'. I racconti, che descrivono lo sfruttamento di tale comunità, presentano una notevole ricchezza stilistica grazie al Indian English, ai prestiti dalla lingua santhali, e al gioco fra i vari registri del testo.
\end{abstract}

Abstract II: This article investigates the interdisciplinary connections between language and literature in the Indian postcolonial context. I argue that a linguistic approach to contemporary Indian English fiction is useful to unpack complex cultural, social and identitarian questions. As a case study, I analyse some of the short stories from The Adivasi Will Not Dance (2017) by Hansda Sowvendra Shekhar, a contemporary author from a marginalised ethnic group of rural India. My methodology benefits from postcolonial studies, sociolinguistics and critical stylistics, to show how Shekhar reshapes the canon by foregrounding Indian English, borrowings from the Santhali language and registers of specialised discourse.

Keywords: language and literature, Indian English, identity, Hansda Sowvendra Shekhar, Adivasi.

\section{Introduction}

This article sets up a preliminary investigation of the deep and persistent connections between language and literature in the postcolonial context (Kachru \& Smith 2008; Talib 2001), in particular by focusing on Hansda Sowvendra Shekhar's Indian English literary production. While contemporary academic discourse has recognised peculiarities and specificities of the two domains of language and literature, with their own specific sets of frames, tools and paradigms, to a certain extent, the two fields are naturally coterminous and related. In fact, language constitutes the building blocks par excellence of literature, creative domains 
and human culture in general, and as such operates a powerful tool for the representation of ideas, experiences and memories.

Clearly, this is a huge theoretical debate that is outside the purpose of the present paper, but my argument regards the necessity to return to the centrality of language in scrutinising literary texts and the benefits that linguistic theories too can provide in the analysis of fiction, with the aim to gain more insights into literary discourse. This type of interpretation, moreover, is particularly relevant in the case of postcolonial literatures, a wide and variegated area in which the question of language has had a remarkable weight in terms of external imposition, but also in the sense of internal appropriation and reinvention of the code. Furthermore, a number of fields of language studies such as critical discourse analysis and critical stylistics have often concentrated on the construction, circulation and reinforcement of ideologies, points of view and identitarian expressions across texts, and such a reflection flawlessly fits into the postcolonial research agenda and its investigation of literary works.

In this paper, I argue that a linguistic (in particular sociolinguistic and stylistic) approach to contemporary Indian English fiction is fruitful and allows to unpack cultural, social and identitarian questions, in particular considering marginalised communities. As a case study, I intend to offer a preliminary analysis of some of the short stories contained in the collection The Adivasi Will Not Dance (2017) by Hansda Sowvendra Shekhar, a contemporary author that belongs to one of the marginalised ethnic groups of rural India. These stories primarily concern the (self)representation of Adivasi identity, but function via a host of complex linguistic and diegetic strategies. I will apply an interdisciplinary methodology informed by postcolonial studies, variation sociolinguistics and critical stylistics, to show how Shekhar reshapes the boundaries of the canon by crafting a polyphonic style that draws from a wealth of different linguistic levels, including the use of Indian English, borrowings from the Santhal language (the mother tongue of the author's ethnic group) as well as elements of specialised discourse (i.e. medical register). This project is in line with recent scholarship that emphasises the correlation and overlapping between language and literature, in particular with regard to the postcolonial world, in which a linguistic lens permits to unearth significant cultural issues. For example, in their exploration of World Englishes, Kachru and Smith (2008: 172) define postcolonial writers as "exponents of creativity", given their capacity to shape and elaborate non-standard forms, whilst Sailaja (2009), in her description of Indian English, utilises a series of literary references too. Furthermore, important Indian English authors such as Vikram Seth, Amitav Ghosh and Arundathi Roy have been innovatively investigated with the aid of linguistic frames and concepts (Bandyopadhyay 2010; Sarangi 2018), thus once again testifying to the interdisciplinary link between language and literature in the postcolonial arena. Here I will take into account a recent and perhaps less known author, whose work however deserves critical attention. Before focusing on Hansda Sowvendra Shekhar's stories, it is vital to outline the theoretical background necessary for the development of my argument.

\section{Theoretical Background: (English) Language and Literature in India}

To understand the complex and stratified presence, role and power of English in India 
today, we need to remember how the language was imported during the colonial period and transformed into a cultural 'object' (Auddy 2020; Bendy 2020). English language implementation was primarily sanctioned by the so-called Macaulay Minute (1835) (Sailaja 2009: 106-110), which not only established the central role of the coloniser's language but also forged the relation between an external hegemonic cultural power and a local cultural context seen as subaltern (Spivak 1988). Schools were set up and teachers followed traditional pedagogical practices in terms of both contents and methods, and the ideal model of English language teaching (ELT) was related to the Anglo-Saxon tradition, from Shakespeare and King James' Bible to the Romantic poets. The literature-based approach to language teaching continued until recently, and as a meta-fictional example I can briefly cite Family Matters (2002), a novel by Rohinton Mistry, in which a retired university professor of English has to be treated in a Mumbai hospital. The doctor who looks after him turns out to be a former pupil of his, during the 1960s, and immediately recalls his English classes about Coleridge and Forster, demonstrating how even ELT for medicine also touched upon literary materials. Aside from questions of disciplinary appropriateness, it is worth noticing that in India the massive and rooted presence of literature in language teaching practices brought to the emergence of a literary flavour of the diatopic English variety, still present today and attested by a range of obsolete linguistic items (Sailaja 2009).

However, the impact of English should be considered within a broader imperial project, which by means of different strategies naturalised conditions of subalternity and otherness, relegating Indians speakers of English into a permanent condition of inferiority and marginality. Due to space restrictions, I am not able to properly dwell on this aspect but suffice to say that with the advent of independence in 1947, the question of language policies and roles acquired even more importance given the intricacy of the new multicultural federal state (Bedi 2020). English accompanied the acknowledgement of Hindi and the other national languages, but at the same time it fully emerged and showed its inner processes of creative stylistic variation. As Ashcroft (2009: 3) holds, "colonial languages have been not only instruments of oppression but also instruments of radical resistance and transformation", in particular thanks to the imaginative power of different waves of Indian authors, from Raja Rao to Salman Rushdie, who have transformed and enriched the coloniser's language. In a similar vein, Denke (2013: 72) affirms that "postcolonial creative writing and theoretical discourse provide ample space for such transformations and refresh the question of the use of imperial language", also challenging and questioning the new role attributed to English in terms of nativised language that is able to express and reproduce local reality and culture.

The relevance of the nexus between language and literature therefore emerges in toto as the two areas are intertwined and contribute to the representation of the cultural landscape of India, including the liminal areas of society, for example the Adivasi community of which I will speak below. If on the one hand literature is a form of fictio, a non-mimetic discourse, on the other, it cannot be denied that it operates as a sort of figurative mirror for the depiction of society and human experience at large, especially in the postcolonial arena, as many scholars and theorists have underlined (e.g. Ashcroft 2009; Talib 2002). From this angle, according to Kachru and Smith (2008: 168), literary works in English "are a valuable source of sociocultural knowledge not easily recoverable from grammars, dictionaries and 
textbooks", and as such can be analysed with the specific purpose to study how different language levels are innovatively elaborated to convey and express cultural meanings in the postcolonial setting. The choice of focusing on the literary work of Shekhar is primarily driven by his capacity to utilise the expressive code in a heteroglossic and dynamic way, hybridising the text with instantiations of Indian English, loanwords from vernacular language and a range of different registers. Moreover, although they belong to the fictional domains, Shekhar's stories incorporate elements of the author's personal experience as an Adivasi medical officer in Jharkhand, and in this light they may be viewed as social narratives that witness one of the numerous contemporary microcosms of India. Thus, the author aligns with original Indian English literary productions that renovate postcolonial genres and address contemporary questions in the formation of what Varughese defines "new India, a new canon" (2013: 13).

\section{Narrating the Adivasi Context}

In this section, I will briefly introduce the Adivasi world, whose name generally refers to the so-called indigenous peoples of India, also known as 'Scheduled Tribes' (Jeffrey and Harriss 2014: 8-9). According to the 2011 Census, these ethnic groups constitute $8.6 \%$ of India's population (i.e. 104 million people), and live in different parts of the country. Their social positioning constitutes a sort of internal discrimination because, in spite of the postcolonial discourse of freedom, independence and recognition of human rights, not only India does not recognise the status of autochthonous population for them, but they are even regarded as 'primitive', totally alienated from society and confined to specific areas and reserves. The colonial policies of segregation inaugurated during the Raj are thus perpetuated, along with the terminology and classification used to define such ethnic groups, whose original lands are very frequently exploited because of the presence of rich mineral resources, as it occurs for example in Jharkhand, a state created in eastern India in 2000 in response to local pressures (Chandra, Mukherjee \& Mukherjee 2008).

In particular, the Santhal represent the largest ethnic group in Jharkhand, although they also live in other states like Odisha, Bihar and West Bengal. In spite of their rich cultural heritage, for instance their colourful dances, the Santhal, like other scheduled tribes and scheduled castes, often have to vacate their territory, where they used to work as farmers, and look for a job in the numerous coalmines that now devastate the landscape. Hansda Sowvendra Shekhar comes from this milieu and in his literary production, seems to index a sort of 'self representation' of Adivasi culture, i.e. a voice within the community, following a broader scheme of postcolonial writers giving visibility to the oppressed and peripheral subjects.

For many postcolonial authors, in fact, the representation of identity and commitment to social (and ethical) questions, including 'minority' groups, is of paramount importance, and frequently this occurs especially via English language works, which can attract national and international interest and therefore communicate with a wider audience in order to raise sensibility and awareness of certain issues. However, the presence of Adivasi in Indian English literature is still peripheral, or based on stereotypes, if not totally absent, according to patterns that have erased, silenced or plateaued the reality of minority groups. 
For Chakraborty (2017: 3-4), for example, the "contemporary representation of Adivasi still follows the colonial paradigm of the 'noble savage', and in accordance with urban Indian stereotypes this romanticising view finds its crystallisation through a representation of Santhal dance".

To debunk such narratives of marginal categories and reverse ideological perspectives, Shekhar's project entails the idea of voicing the subjugated Adivasi community, but at the same time it also delves into the notion of problematizing the very sense of community, i.e. exposing controversial issues and questions. In other words, Shekhar's stories are particularly salient because they are governed by an unbiased attitude and thus they seem to encourage a rethinking and revision of Indian English literature in order to create a new map of Adivasi culture and identity, going beyond static clichés. To carry out his literary discourse, the author has turned to linguistic heteroglossia that combines and overlaps different registers and specialised vocabulary (e.g. music, mining, medicine as well as idiolectical and figurative expressions), but more importantly he has employed code mixing between Indian English and vernacular (Adivasi) language, with the ultimate target of "refashioning the English language to suit the Santhali sentiments" (Tripathi 2017: 195).

\section{Language, Literature and Adivasi Stories Within and Outside the Community}

Collecting ten stories, some of which previously published in periodicals, the book under consideration deals with the reaction of Adivasi people towards the challenges posed by the radical exploitation and implicit annihilation of Jharkhand, a wide process often disguised as a development of new opportunities leading to modernity, progress and welfare for all. As a whole, the volume obtained a good reception from readers who appreciated the writer's style in handling a discourse of ethnic and social discrimination that foregrounds the contradictions of contemporary Indian economic growth at the expense of disadvantaged subjects. However, the stories caused a heated debate, in particular within the Adivasi community itself, for the controversial portrayal of some of its members. As a matter of fact, rather than offering a reassuring description of his own community, the writer has provokingly criticised and unveiled hidden sides of the Adivasi cultural identity by means of a clever manipulation of the linguistic texture. The author's innovative use of various linguistic devices and patterns, however, does not merely aim at generating aesthetic and poetic effects of defamiliarisation, but plays a key role in the thematic organisation of the writing. In Chakraborty's (2017: 5) view, for example, it is "one component of the representational matrix through which the radical Otherness of the Adivasis as subalterns is foregrounded in the text". To put the same point otherwise, the linguistic peculiarity of the text is functional in the treatment of questions, in particular concerning local identity and liminality, thus demonstrating once again how, in the postcolonial scenario, language and literature seem to function in tandem to corroborate the manifestations of culture. I will now take into account a couple of these stories and will analyse a number of passages from both, using linguistic and stylistic tools.

Constructed as a sort of monologue narrated by a Santhal farmer and musician called Mangal Murmu, the eponymous story "The Adivasi Will Not Dance" expands on the general 
crisis that constantly threatens and impoverishes tribal society in terms of both material commodities and immaterial culture. The old narrator, in a confessional tone, explains to a mute interlocutor, perhaps a journalist, how mining companies supported by the government are in reality responsible for forced eviction and eradication that have determined the social disintegration of the Santhal community in spite of the national rhetoric that celebrates the development of the area as well as the apparent recognition of local ethnic and cultural groups. Even symbols of Adivasi art such as dance and music have been depredated and turned into orientalising commodities. When the authorities organise a public ceremony for the laying of the foundation stone for a large thermal power plant in Godda, they ask Murmu and his fellows to play and dance for a very special guest, the President of India. Their intention is to offer a kind of folkloristic spectacle that should symbolise unity of the country and multiculturalism, whilst in reality it is an act of power grounded upon the effects of neoliberal policies that ruthlessly abuse the natural and human environment. Mangal Murmu accepts and arranges a troupe of artists for the event, but when he finally stands in front of the President, he cannot control his anger and misery, and delivers a provoking discourse of denunciation, with disastrous consequences.

I will now look at three passages taken from this story to show how the text gains in complexity through a range of linguistic structures and forms. These plot-advancing elements are entrenched in the cultural paradigm of postcoloniality and foster empathetic bonds.

But we Santhals are fools, aren't we? All of us Adivasis are fools. Down the years, down generations, the Diku have taken advantage of our foolishness. Tell me if I am wrong. I only said, "We Adivasis will not dance anymore" - what is wrong with that? We are like toys - someone presses our ' $\mathrm{ON}^{\prime}$ ' buttons, or turns a key in our backsides, and we Santhals start beating rhythms on our tamak and tumdak, or start blowing tunes on our tiriyo while someone snatches our very dancing grounds. Tell me, am I wrong? (170).

Such diseases that we can't breathe properly, we cough food and forever remain bare bones. For education, our children are at the mercy of either those free government schools where teachers come only to cook the midday meal, or those Kiristan missionary schools where our children are constantly asked to stop worshipping our Bonga-Boru and start revering Jisu and Mariam. If our children refuse, the sisters and the fathers tell our boys that their Santhal names - Hopna, Som, Singari - are not good enough. They are renamed David and Mikail and Kiristofer and whatnot. And as if that were not enough, Muslims barge into our homes, sleep with our women, and we Santhal men can't do a thing (172).

It is this coal, sir, which is gobbling us up bit by bit. There is blackness - deep, indelible - all along the Koyla Road. The trees and shrubs in our village bear black leaves. Our ochre earth has become black. The stones, the rocks, the sand, all black. The tiles on the roofs of our huts have lost their fire-burnt red. The vines and flowers and peacocks we Santhals draw on the outer walls of our houses are black. Our children - dark-skinned as they are - are forever covered with fine black dust. When they cry, 
Vol. XVIII-No. 20 November 2020

and tears stream down their faces, it seems as if a river is cutting across a droughtstricken land. Only our eyes burn red, like embers (174).

The three extracts are, first of all, characterised by stylistic hybridity which manifests itself through borrowing from different sources, such as jawan (attested in the Oxford English Dictionary from Urdu with the meaning of 'soldier') or Santhal words, for example with honorifics like Diku (indicating an 'outsider' but also a 'moneylender') or technical terms for musical instruments (tamak / tumdak). In the postcolonial field, the presence of loanwords and codemixing reflects the vivacity of a culture, but it also has a political and social meaning because "refusing to translate words not only registers a sense of cultural distinctiveness, but also forces the reader into an active engagement with the vernacular culture" (Ashcroft 2009: 176). Moreover, foregrounding the Santhal language is an act of recognition for a language that struggles to emerge and acquire its own visibility and independence (Choksi 2017).

The author's stylistic creativity also takes the form of 'eye dialect' (Wales 1995: 167), namely a sort of misspelling that tries to orthographically reproduce the dialectical pronunciation of the term: for Shekhar, this device is more than a simple phonological embellishment because names like 'Kiristian/Jisu/Marian' alludes to the complexity of the religious sphere as Adivasi people are directly and indirectly pushed to conversion to some official faith, such as Christianity or sometimes Hinduism. This point is of particular interest when considered in connection with the discourse of naming, which constitutes a pillar of cultural and societal organisation. The demolition of the Santhal community, in fact, is also carried out by onomastic practices that impose foreign (i.e. western and Christian) names on children, thus obliterating their cultural heritage. Other important strategies that contribute to the general makeup of the story comprise the use of inclusive pronouns ('we'), by which the speaking character refers to his broad ethnic group, implicitly in opposition to external subjects. The excerpts also display the persistence of parallelism and listing patterns, both as lists of lexical items (for instance 'the trees / the stones / the tiles') as well as entire clauses (we + verb structure), which cumulatively strengthen Murmu's lamentation.

In the extracts and the entire story, repetition is an especially productive device when it concerns chromatic allusion and symbolism: because of the unwise, extensive and destructive mineral extraction, the predominant colour that seems to completely shroud people, animals and the environment is black as shown by an abundance of related lexical items such as 'coal' or 'blackness'. But the chromatic suggestion is even more linguistically powerful because it seems to create a before/after effect, namely the state of beings and things before and after the pernicious advent of unlimited extraction, so that bright and vivid colours ('ochre earth') that used to characterise natural and cultural life are now replaced by dark, almost fiendish hues. The consequence of the black devastation is even highlighted by the temporal adverb 'forever', which produces permanent effect, already anticipated by the preceding adjectives 'indelible' and 'black'. Moreover, it is worth noticing that coal representing the colour black is figuratively given agency, in a transitive form (with the noun phrase 'gobbling us up bit by bit'), and becomes a sort of monstrous metaphor for the extinction of the Santhal community. Even when a colour other than black is quickly evoked 
('red'), it expresses a negative meaning as the term collocates with the images of burning ashes that cause much suffering.

The multivoicedness of Shekhar's writing as a means for representing a complex community and context runs throughout the collection, and I will now move to another story, entitled "November is the Month of Migrations". The narrative follows Talamai Kisky, a 20-year-old Christian girl who, like many other Adivasi people, has to travel to West Bengal looking for a job, and foregrounds another type of exploitation to which the Adivasi are sometimes subjected, namely that of physical and sexual nature. Given the sensitivity and controversy of the theme, which also pervades another story, entitled "Merely a Whore", the readers' response was quite shocked and rather unsupportive of an Adivasi author exposing and deconstructing some scandalous issues of his own community. The following extract captures the general atmosphere of the text:

Come November, Santhal men, women and children walk down from their villages in the hills and the far-flung corners of the Santhal Pargana to the railway station in the district headquarters. These Santhals-villages, entire clans- make up long, snaking processions as they abandon their lands and farms to take the train to Namal, the Bardhaman district of West Bengal and the paddy fields there. In the month that these Santhal families will spend in Bardhaman, they will plant rice and other crops in farms owned by the zamindars of Bardhaman, they will plant rice and other crops in farms owned by the zamindars of Barhaman. [...] Talamai walks away from her group. She has been attracted by a man. He is young, fair, a Diku, and a jawan of the Railway Protection Force. A bread pakora in hand, he has signalled her to approach and has disappeared round a corner. [...]

"Are you hungry?" the jawan calls out as Talamai rounds the corner. "You need food?" He is standing in front of the policemen's quarters.

"Yes", Talamai answers.

"You need money?"

"Yes."

"Will you do some work for me?"

"Yes." Talamai knows what work he is talking about. She has done it a few times by the Koyla Road, where many Santhal women and girls steal coal from trucks. She knows many girls who do that work with truck drivers and other men. And she knows that on their way to Namal, Santhal women do this work for food and money at the railway station too (39-40).

In a nutshell, the story illustrates "the painful, disturbing and sad state of Adivasi for whom every day was a struggle to survive" (Tripathi 2017: 194) by using a style that contrasts with the descriptive and apparently plain title. The diatopic linguistic dimension is signalled by borrowed or non-standard terms, for instance zamindar (indicating a landowner and originally an aristocrat, from a Persian root), but we should also pay attention to the shift in focalisation whereby the story is narrated via an omniscient voice, but provides the perspective of the girl. Here the discourse of sexual exploitation becomes a disturbing allegory for the general mistreatment of the territory and its natural community, with a 
parallelism between the body of the character and the surrounding land, both being violated by an external force. The moral brutality of the scene, when the dire conditions of everyday life force women to prostitution, is hidden within the question-and-answer structure that forms the conversation between the two characters and naturalise the soldier's hypocrisy in offering food to a young girl in exchange for sex. Equally significant is the underlexicalisation process functioning through general or vague, and yet attention-getting, words ('some work', 'what work', 'that work') that actually replace and refer to unspeakable or taboo concepts. The scandalous treatment of the sexual and bodily aspect of the story sustains heteroglossia, with the Bakhtinian sense of the 'carnivalesque', i.e. an excessive embodied form of representation to contrast the idea of power and the establishment in a provoking and distressing way. If the reference to prostitution and sexual exploitation certainly irritates many members of the Adivasi community, it nonetheless discloses unsaid truth from within the community and abolishes any form of insincerity, attesting the ethical commitment of the postcolonial writer to his work.

Overall, the pragmatic effects of this kind of multi-voiced writing are linked to the multiple reactions that the readers experience toward the text in terms of language and style. As I have briefly mentioned, Shekhar's stories have attracted mixed reactions given the series of questions he touches upon in his production. Positive responses have been in relation to the question of human and natural mistreatment of the Adivasi territory and people, and have appreciated the amalgamation of different voices for a complex context. Yet negative responses have come from some Adivasi readers, who have strongly criticised the breach of the sense of origin and belonging, and even rejected the text. For them, selecting a topic that exposes the community's inner tensions remains deplorable. Both types of reaction are a way to approach the author's construction of a fictional narrative that pivots around his effort to unpack the voice within and across the Adivasi community. As Talib (2002: 133) affirms, "attitudes towards language in fiction are very often reflective of, or are affected by, what goes on outside it". By manipulating and transforming the language paradigm, Shekhar's writing offers a provoking self-representation of a portion of postcolonial Indian society to foreground marginalised subjects.

\section{Concluding Remarks}

In this article, I have focused on the interdisciplinary connection between language and literature in the postcolonial world and have sketched out the benefits of a linguistic and stylistic approach to Indian English fiction, specifically concentrating on Hansda Sowvendra Shekhar, an Adivasi author whose stories evoke and denounce discourses of marginalisation, exploitation and erasure. For the writer, polyphony, hybridity and language variation can be regarded as tools for meaning making in the narrative representation of a community, constantly threatened by neoliberal waves of modernity disguised as modernity, development and progress. In this vein, Shekhar's short stories are texts that challenge the reader thanks to idiolectal language choices and convey the author's impartial idea of (self)representation of a specific cultural group, going beyond a strict prejudice of belonging.

Using the case study of Shekhar's provocative stories, I have suggested that in the 
postcolonial context language and literature should be seen as two disciplinary domains that function hand in hand, in a scenario in which questions of language, power and identity are interweaved and impact on society, and its textual representations at large. An examination of Indian English literary texts that also employs theories, tools and frames from fields such as sociolinguistics or stylistics constitutes a critical enhancement because it acknowledges how the problem of language has informed genres and inspired authors to engage with culture. In this regard, language is more than a code of communication and becomes an arena of confrontation in which the mechanics of culture function and produce meaning through the cogs of multi-layered history, reminding us how English is intimately part and parcel of both colonialism and postcolonialism, being an imperial language and a means of emancipation at the same time. This type of interdisciplinary approach to postcolonial discourse thus encourages an inclusive revision of the very idea of canon and raises awareness of some of the issues, complexities and entanglements that characterise the world we live in.

\section{BIBLIOGRAPHY}

Auddy, Ranjan Kumar. 2020. In Search of Indian English. History, Politics and Indigenisation. Abingdon: Routledge.

Ashcroft, Bill. 2009. Caliban's Voice. The Transformation of English in Post-Colonial Literatures. London: Routledge.

Bandyopadhyay, Sumana. 2010. Indianisation of English. Analysis of Linguistic Features in Selected Post-1980 Indian English Fiction. New Delhi: Concept Publishing Company.

Bendi, Jaskiran. 2020. English Language in India. A Dichotomy between Economic Growth and Inclusive Growth. Abingdon: Routledge.

Census of India 2011 https: / / censusindia.gov.in/2011-common/ censusdata2011.html (consulted on $13 / 05 / 2020$ ).

Chakraborty, Abin. 2017. Examining Subalterneity in Hansda Sowvendra Sekhar's The Adivasi Will Not Dance. Postcolonial Text, 12, 1:1-15.

Chandra, Bipan, Mridula Mukherjee \& Aditya Mukherjee. 2008. India since Independence. Gurgaon: Penguin Random House India.

Choksi, Nishaant. 2017. From Language to Script: Graphic Practice and the Politics of Authority in Santali-language Print Media, Eastern India. Modern Asian Studies, 51, 5: 1519-1560.

Denke, Charles Ngiewih. 2013. The Vulnerability of Imperial Language as a Transformational Tool in Postcolonial Transcultural Discourse. Academic Journal of Interdisciplinary Studies, 2, 3: 71-81.

Jaydeep, Sarangi. 2018. Indian Novels in English. Texts, Contexts and Language. New Delhi: Authors Press.

Jeffrey, Craigg \& John Harriss. 2014. Keywords for Modern India. Oxford: Oxford University Press.

Kachru, Yamuna \& Larry E. Smith. 2008. Cultures, Contexts and World Englishes. New York: Routledge. 
Oxford English Dictionary online. 2020. www.oed.com (consulted on 12/05/2020). Sailaja, Pingali. 2009. Indian English. Edinburgh: Edinburgh University Press. Shekhar, Hansda Sowvendra. 2015. The Adivasi will not Dance. New Delhi: Speaking Tiger. Spivak, Gayatri. 1988. Can the Subaltern Speak? Nelson Cary \& Lawrence Grossberg eds. Marxism and the Interpretation of Culture. Urbana (ILL): University of Illinois Press, 271-313. Talib, Ismail. 2002. The Language of Postcolonial Literatures. London: Routledge. Tripathi, 2017. The Adivasi Will Not Dance: Stories by Hansda Sowvendra Shekhar. Rupkatha Journal on Interdisciplinary Studies in Humanities, 9, 4: 193-196.

Varughese, E. Dawson. 2013. Reading New India. Post-Millennial Indian Fiction in English. London: Bloomsbury.

Wales, Katie. 1995. A Dictionary of Stylistics. London: Longman.

Esterino Adami is Associate Professor of English language and translation at the University of Turin. His main research areas include postcolonial writing, critical stylistics and language studies. He has published extensively on lexical aspects of Indian English, the narrative rendition of specialised discourse, and the semiotics of Indian comics. He has authored Railway Discourse. Linguistic and Stylistic Representations of the Train in the Anglophone World (2018) and co-edited Other Worlds and the Narrative Construction of Otherness (2017, with F. Bellino and A. Mengozzi) and Within and Across: Language and Construction of Shifting Identities in Post-Colonial Contexts (2012, with A. Martelli).

esterino.adami@unito.it 